\title{
Nağīb al-Kīlānī and the Islamic Storyteller
}

\author{
Samira al-Khawaldeh \\ The University of Jordan \\ s.khawaldeh@ju.edu.jo
}

\begin{abstract}
Nağīb al-Kīlānī is an Egyptian novelist and theorist whose work acquires more importance by virtue of its unique position as a literary manifestation of the thought and worldview of the Society of the Muslim Brotherhood. To embark on such a writing career in Egypt at mid-twentieth century meant first the antagonisation of certain power centers, leading to political jail, and ultimate diaspora; and second addressing the task of transforming the rudimentary conjecturing about an Islamic theory of art into a somewhat systematic form of theorization. The study thus aims to investigate al-Kìlān's contribution to the foundation of a theory of Islamic novel, focusing on his approach to the dilemmas and ambiguities surrounding the role of the modern Islamic novelist such as maintaining the intricate balance between the demands of religion and the freedom of art.
\end{abstract}

\section{Keywords}

Nağīb al-Kīlānī, Islamic literature, Islamic novel, Islamic realism, Islamic theory of literature, Muslim Brotherhood

\section{Résumé}

Nağīb al-Kīlānī est un romancier et théoricien égyptien dont le travail acquit une importance en raison de sa position unique en tant que manifestation littéraire de la pensée et de la vision du monde des Frères musulmans.

S'engager dans une telle carrière d'écrivain en Égypte au milieu du vingtième siècle signifiait d'abord se trouver en porte-à-faux avec certains centres de pouvoir, menant à la prison pour motifs politiques et à l'exil définitif, et, deuxièmement, s'atteler à la tâche de transformer les rudiments d'une théorie islamique de l'art en une forme 
quelque peu systématique de théorisation. L'étude vise donc à étudier la contribution d'al-Kīlānì à la fondation d'une théorie du roman islamique, en se concentrant sur son approche des dilemmes et des ambiguïtés entourant le rôle du romancier islamique moderne, comme le maintien de l'équilibre complexe entre les exigences de la religion et la liberté de l'art.

\section{Mots clefs}

Nağīb al-Kīlānī, littérature islamique, roman islamique, réalisme islamique, théorie islamique de la littérature, Frères musulmans

\section{Introduction}

In a 1989 interview, Nağīb Maḥūz, the Egyptian Nobel Laureate for literature, describes Nağìb al-Kīlānī (1931-1995) as the "theorist of the Islamic novel"; '1 thus earmarking a category in the genre of novel as "Islamic" along with its theoretical framework, distinguishing it by implication from other works of fiction including Maḥfūẓ' own. As Maḥfūz seems to have already decided on the ontological aspect of the subject, what this study seeks to unravel is the bases of this assumption, the concepts and parameters that demarcate and define Maḥūz' terms of "Islamic novel," its "theory," and al-Kīlānī's contribution to both.

To begin with, one must trace the genealogy of the recently developed discipline dubbed "Islamic literature." Historically speaking, such a classification scheme is altogether new. Many centuries ago, the boundaries of the term "Islamic" consisted of a simple binary: Islamic and Pre-Islamic, established on chronology and not the matter of content. However, the Islamic era witnessed the introduction of a rich literary glossary but not "Islamic" or "un-Islamic" in a definitive sense. In the fourth/tenth century and in his al-Fihrist, Ibn al-Nadìm (d. 385/995 or 388/998), contemptuously lists The One Thousand and One Nights in a compendium of Arabic books under the genre of "evening storytelling" (samar) and "myth-narrativization" (tahrîf), censuring it as "a really

1 Al-Mușawwar (13 October 1989), quoted in the Muslim Brotherhood's official online encyclopedia al-Mawsū'a l-tārīhiyya li-Ğamā'at äl Ihwwān al-Musliminn, http://www.ikhwanwiki.com/ index.php?title=\%D9\%86\%D8\%AC\%D9\%8A\%D8\%A8_\%D8\%A7\%D9\%84\%D9\%83\%D9 \%8A\%D9\%84\%D8\%A7\%D9\%86\%D9\%8A, accessed 04/o9/2015. 
inane and improper discourse" ( $\dot{g} a \underline{t} \underline{t} w a-b a \bar{r} i d$ al-hadīt $),{ }^{2}$ two qualities opposed to the new Islamic definitions, but not as "un-Islamic."

In modern times, though the actual term has been sporadically used by one writer or another, ${ }^{3}$ the first known serious discussion of what has come to be branded as "Islamic literature" appears in an essay by the then spokesman of the Muslim Brotherhood, Sayyid Quṭb, entitled Manhağ li-l-adab (An Approach to Literature), published in $1952 .{ }^{4}$ There, he defines literature as a "suggestive expression of a living experience," and without using the term adab islämì speaks of "literature that emanates from an Islamic conception of life," outlining its basic characteristics that later critics have kept intact. ${ }^{5}$ Other thinkers follow, contributing to the project of formulating a contemporary theory. Muhammad Quṭb (1919-2014) published his book Manhağ al-fann alislāmī (The Islamic Approach to Art) in 1961, Nağīb al-Kīlānī his al-Islämiyya wal-mad̄āhib al-adabiyya (Islamism and Literary Approaches) in 1962, and 'Imād al-Dīn Halīl (born in 1941) his Fì l-naqd al-islāmì l-mu'āṣir (On Contemporary Islamic Criticism) in 1972, among others.

Nağỉb al-Kīlānī is an Egyptian novelist and theorist whose work acquires more importance from its unique position as a literary manifestation of the thought and worldview of the Society of the Muslim Brotherhood. Joseph A. Massad straightforwardly describes him as "a major and pioneering contemporary Islamist novelist," ${ }^{6}$ and in Fedwa Malti-Douglas' account he is "a physician and a creative writer of Islamic literature, [who] has written some provocative works on Islamism and literature."7 To other scholars, he is simply "a physician in the Ministry for Health, Cairo, and a successful novelist." ${ }^{\text {B }}$ Besides being officially a member of the organization, ${ }^{9}$ mapping the themes in his fiction and the perspectives he adopts certainly reveals close affinity with the movement's intellectual world. On the other hand, although his novels number more than

2 Ibn al-Nadīm, Kitāb al-Fihrist, ed. Ayman Fu’ād Sayyid, London, Mu’assasat al-furqān li-lturāṭ al-islāmī, 2009, p. 322.

3 See Māğid b. Muhạmmad al-Māğid, "al-Adab al-Islāmī: Murāğacāt fì l-naša wa-l-ḩașāiș̣," Mağallat 'ālam al-kutub, 25/2-3 (2003), p. 133-155.

4 Šaltāò 'Abbūd, al-Malāmị al-āmma li-nazariyyat al-adab al-islāmī, Damascus, Dār alma'rifa, 1992, p. 24.

5 Sayyid Quțb, Fù l-tārīh fikra wa-minhāğ, Jeddah, al-Dār al-sa'ūdiyya li-l-našr, 1967, p. 11-21.

6 Joseph A. Massad, Desiring Arabs, Chicago, University of Chicago Press, 2008, p. 222.

7 Fedwa Malti-Douglas, Medicines of the Soul: Female Bodies and Sacred Geographies in a Transnational Islam, Berkeley, University of California, 2001, p. 6.

8 Jacob Landau, The Politics of Pan-Islam: Ideology and Organization, Oxford, Clarendon Press, 1990, p. 263

9 See al-Mawsū'a l-tārīhiyya li-ğamāàt àl Iḩwān al-Musliminn, accessed 04/o9/2015. 
forty, only Rihla ilā Llāh (A Journey to God), published in 1978, directly delves into the Brotherhood's history, serving both as a counter narrative to Nasser's propaganda and as an autobiographical account. Generally endorsed by the literary-minded among its members, ${ }^{10}$ his work may well be taken to represent a semi-official discourse of the collective consciousness of the Brotherhood, which has produced several poets of recognition, ${ }^{11}$ but so far al-Kīlānī seems to be its major, if not its sole, novelist. Still, there are key points where he diverges from the movement's long-standing conventions.

To embark on a writing career in Egypt at mid-twentieth century meant the shouldering of many responsibilities, as al-Kīlānī found himself confronted on one side by colonialism, totalitarianism, jail, and the ultimate diaspora, and on the other by the dilemmas and ambiguities surrounding the role of the modern Islamic artist such as maintaining the intricate balance between the restrictions and demands of religion and the freedom of art. In fact, this is the first attempt to address the technicalities of the subject, trying to steer it away from the religious polemics that dominate, according to him, Muhammad Quṭb's theorization. ${ }^{12}$ In his experimentation with new terms, al-Kìlānī comes up with "Islamic realism"; but when the small circle of interested critics later adopt it as the official mode of Islamic literature, the translation of the concept into tangible narratives proves to be extremely problematic. Al-Kīlānī himself finds some of his own novels scathingly censured, especially for their persistent and prominent portrayal of female characters and the occasional mention of sexual experience.

\section{Towards a Definition}

Nağīb Maḥūẓ' statement above, as well as al-Kīlānī's initiative towards the formulation of an autonomous conception of "Islamic literature," seem to reflect the urgency of such categorization due to the ideological diversification dominating Arab cultural life since the beginning of the twentieth century, with the spread of secularism, communism and other trends. Al-Kīlānī argues that an Islamic theory of literature is required to fill in a slot left vacant among

\footnotetext{
$10 \quad$ Ibid.

11 An acclaimed poet affiliated with the Muslim Brotherhood is 'Umar Bahā’ al-Dīn al-Amīrī (1918-1992). See also Aḥmad al-Ğada', Šu'arä’ al-da'wa l-islämiyya fíl-'aṣr al-ḥadīt, Amman, Dār al-ḍiyā', 2011.

12 Nağīb al-Kīlānī, al-Istāmiyya wa-l-mad̄āhib al-adabiyya, Beirut, Mu’assasat al-risāla, 1981, p. 7 .
} 
emerging schools such as marxism, realism, and existentialism. Besides, he notices the upsurge of publications covering, from Islamic perspectives, a wide spectrum of subjects such as philosophy, economics, and sociology, and expresses the need for a similar perspective on literature. ${ }^{13}$ Some contemporary studies propose a comprehensive definition following automatic, spatio-temporal terms instead of those of content and consciousness:

"Islamic literature," then, is best understood as the total literary output of Muslims and those influenced by Islamic civilization. Accordingly, it comprises works in Arabic, Chinese, Hausa, Indonesian, Persian, Swahili, Turkish, Urdu, and dozens of other languages, including English. ${ }^{14}$

Still, the general tendency appears to favour the view of autonomous spatiality, of seeing it as inhabiting "a space parallel to that of the mainstream Arabic literary corpus and is," to quote Fedwa Malti-Douglas, simultaneously "dialectically engaged with it." ${ }^{\prime 5}$ Malti-Douglas is one of the very few who have recognized a legitimacy for the literary phenomenon of "Islamic literature." In her other study entitled "Postmoderning the Traditional in the Autobiography of Shaykh Kishk," she states that Islamic literature has been "until now largely occulted in the Western critical corpus," and that few observers have noted "the deep influence that this transnational movement has had on the literary map of the Muslim world." In her analysis, she seems to refer this "occultation" to the secular beginnings of Arabic fiction. ${ }^{16}$

Reuven Snir, another observer, notices that the "non-canonical" status of Islamic literature is due entirely to its mixing of religion with literature; a mode that "guaranteed that a writer be marginalized and driven out of the secular literary canon."17 Ironically, al-Kîlānī himself, though aware of the modern art/

13 Ibid., p. 5 .

14 Shawkat M. Toorawa, "Islamic Literatures: Writing in the Shade of the Qur'an," in Voices of Islam, ed. Vincent J. Cornell, Westport, Connecticut, Praeger, 2007, IV [Voices of Art, Beauty, and Science], p. 121.

15 Malti-Douglas, Medicines of the Soul, p. 5-6.

16 Fedwa Malti-Douglas, "Postmoderning the Traditional in the Autobiography of Shaykh Kishk," in Tradition, Modernity, and Postmodernity in Arabic Literature: Essays in Honor of Professor Issa J. Boullata, ed. Kamal Abdel-Malek and Wael B. Hallaq, Leiden-Boston-Köln, Brill, 2000, p. 389-410.

17 Reuven Snir, Religion, Mysticism and Modern Arabic Literature, Wiesbaden, Germany, Otto Harrassowitz ("Mîzân: Studien und Texte zur Literatur des Orients”, 12), 2006, p. 22. 
religion dichotomy, traces a genealogy of an organic unity binding the two from early paganism and ancient Egypt to Michelangelo and the Renaissance. ${ }^{18}$

What sets this genre apart, in Malti-Douglas' analysis, is its "clear religious agenda"; 19 or, in sociocritical analysis, its concealed social values. One aim of the present study is to investigate this "agenda" and to highlight Islamic literature's philosophy of communicating its conception of the world as it is and as it should be, taking its cue from Marc Angenot's postulation that "All discourses and languages are ideological,"

which means that whatever may be registered and identified in them bears the marks of ways of knowing and representing the known world that are neither a matter of course nor necessarily universal, but that conceal specific social values, express more or less indirectly social interests, and occupy a given position in the economy of discourses of a given time..$^{20}$

This special knowledge of the world is implied in the "Islamic" part of the term. "To say 'Islamic literature," Malti-Douglas explains, "is to call attention to a special kind of relationship between Islam and literature," - a relationship not necessarily restricted to a specific movement; a "literary production with

\footnotetext{
18 Al-Kīlānī, al-Islāmiyya, p. 17-20.

19 Malti-Douglas, Medicines of the Soul, p. 6. It appears that the term "Islamic literature" has become less of a problematic, gaining recognition in recent years as denoting more or less the definition formulated by Malti-Douglas. See for instance Johann Christoph Bürgel, "Islam Reflected in the Contemporary Literature of Muslim Peoples," transl. Karen Margolis, in Islam in the World Today: A Handbook of Politics, Religion, Culture, and Society, eds Werner Ende and Udo Steinbach, Ithaca-London, Cornell University Press, 2010. Bürgel itemizes under the general concept of Islamic literature a number of thematic subgenres, such as Koranic, Muhammad, historical, and fundamentalist (the latter he alternately labels "Islamist" or "Islamic") fiction. Malti-Douglas, meanwhile, finds the term "fundamentalist" "misleading" because of its origin and strong connotations as an American Protestant marker. Malti-Douglas, Medicines of the Soul, p. 2. Bürgel believes "fundamentalist" fiction "runs to several hundred titles," and considers al-Kīlānī as "one of its leading protagonists." He quotes al-Kīlānī as saying, "The main goal [...] of Islamic fiction is to propagate the Islamic worldview and promote the establishment of Islamic society." Bürgel, "Islam Reflected in the Contemporary Literature of Muslim Peoples," p. 802,827 .

20 Marc Angenot, "What Can Literature Do? From Literary Sociocriticism to a Critique of Social Discourse," transl. Robert F. Barsky, The Yale Journal of Criticism, 17/2 (2004), p. 217.
} 
a clear religious agenda has been labeled Islamic literature, differentiating it from its more secularized cousin."21

In his theorization, al-Kïlānī shares this emphasis on the text, thus liberating the term "Islamic" from denominational origins: validation of the knowledge transmitted does not depend on the writer's identity, but on its compatibility with Islam's Weltanschauung. Anticipating the poststructuralist concept of "Death of the Author,"22 this idea is not al-Kỉānī's invention. In his introduction to his al-Islammiyya wa-l-madāhib al-adabiyya, he mentions that Muhammad Quṭb's study of Islamic art resorts to works by Rabindranath Tagore (d. 1941) and John Millington Singe (d. 1909) to illustrate what Quṭb envisions as the characteristics of Islamic literature, a fact that poses no problem to al-Kìlānī. What he complains about is the way Quṭb utterly ignores well-established names in modern Arabic literature, such as Mușțafā Șādiq al-Rāfici (d. 1937), Aḥmad Šawqī (d. 1932), Ḥāfiẓ Ibrāhīm (d. 1932), and 'Alī Aḥmad Bākațīr (d. 1969), among others. ${ }^{23}$ In his turn, he picks for illustration works by Egyptian mainstream writers; namely, Maḥfūẓ, Tawfīq al-Ḥakīm (d. 1987) alongside Bākațīr and Ahmmad Muharram (d. 1945). Equally interesting is al-Kīlānī’s enthusiasm for the medieval skeptic Abū l-Alā' al-Ma'arrī (d. 449/1058) citing him side by side with Sufi poets. To him, al-Ma'arrī's anxieties and doubts, represent a defining feature in Islamic thought as well as a "testimony to the freedom and innovation in the history of Arabic literature." ${ }^{24}$ According to Malti-Douglas, al-Kīlānīs choice of a short story by Maḥfūz may not be "propitious," for he is fully aware of the repugnance of religious thinkers to Mahfüz' recently published novel Awläd häratinā (The Children of Gebelawi). ${ }^{25}$ Perhaps this explains her description of al-Kilānī's work, mentioned earlier, as "provocative."

This answers the question of whether literature written by non-Muslims, those alien to Muslim culture, or by nominal Muslims with areligious orientations can be appreciated as a source of knowledge. Evidently, the answer has to be in the affirmative or Muslim readers will be left with a scanty corpus displaying a uniform worldview. The claim that this line of reasoning is authentic in the Islamic approach is based, in al-Kilānī's perception, on the idea that it "is not tied to a specific geographical spot, or to a state with a particular form of religion, $[. .$.$] it glorifies the universal values of love, fraternity, cooperation,$

\footnotetext{
21 Malti-Douglas, Medicines of the Soul, p. 6.

22 Roland Barthes, "The Death of the Author," in Image Music Text, transl. Stephen Heath, London, Fontana Press ("Flamingo"), 1977, p. 142-148.

23 Al-Kīlānī, al-Islāmìyya, p. 6.

24 Ibid., p. 88.

25 Malti-Douglas, Medicines of the Soul, p. 6.
} 
courage, justice, and mercy."26 Muslims' ancestors, he argues, present a great role model in their methodological reading and translation of the heritages of ancient civilizations, Greek, Indian, or Persian. ${ }^{27}$

Thus, in their selections, Quṭb and al-Kīlānī disregard geographical, historical and religious origins. Only the text matters. Quṭb discusses Muhammad Iqbal and Tagore in more or less the same appreciative tone:

Tagore of course is not Muslim. Evidence of his Hinduism is discernible in the sweet tolerance, the spiritual purity, the flowing love for life and the living, and existence only through the greater being, in affection, friendship and fraternity. ${ }^{28}$

There is, however, as he continues, one reservation: "his passivism!" Apparently, while celebrating Tagore's harmonious, cosmic spirituality, which he finds akin to Islam, he regrets its totally "dreamy unrealistic" nature. Yet, in a gesture that relegates author's identity and agency, and because the similarities outweigh the differences, Quṭb indorses Tagore; ${ }^{29}$ albeit his definition of Islamic art is "the aesthetic expression of the Islamic conception of the universe, life, man and existence." 30

Al-Kïlānì displays a similar inclusive temperament. Arguing for the legitimization of comedy and satire within Islamic literature, he upholds George Bernard Shaw (d. 1950) and Henrik Ibsen (d. 1906) as the best examples for their constructive influence on society. They are great artists, he explains, who target the social plights and corruption in their milieu, raising issues of universal appeal. ${ }^{31}$ This leaves us with the impression that defining Islamic literature and setting up a relevant theory works not in terms of what it can comprise, for this is left open, but of what it cannot; i.e. in terms of exclusion, basically rejecting those works that reflect or propagate a materialistic and/or immoral worldview. Such definitions "demonstrate the fluidity of what constitutes Islamic literature," to borrow Malti-Douglas' expression. ${ }^{32} \mathrm{Al}-\mathrm{Ki} l a ̄ n \overline{1}$, in particular, cedes that Egyptian mainstream writers, such as Šawqī, Ḥāfiz Ibrāhīm, Ṭāhā

$26 \quad$ Ibid., p. 31.

27 Al-Kīlānī, Madhal ilā l-adab al-islāmmī, Doha, Ri’āsat al-maḥākim al-šar'iyya wa-l-šu’ūn aldīniyya ("Kitāb al-umma", 14), 1987, p. 22.

28 Muhammad Quṭb, Manhağ al-fann al-islāmī, Beirut, Dār al-šurūq, 1983, p. 199.

29 Ibid., p. 200-202.

$30 \quad$ Ibid., p. 6.

31 Al-Kīlānī, al-Islāmiyya, p. 35.

32 Malti-Douglas, Medicines of the Soul, p. 7 . 
Ḥusayn (d. 1973), and even Nağîb Maḥfūz and Tawfìq al-Ḥakīm, have all written works that fall within his own definition of Islamic literature. ${ }^{33}$ 'Imād al-Dīn Halil meanwhile resorts to a jurisdictional rule that deems all things originally lawful unless specifically judged otherwise in legal sources. Extending the rule to the literary domain means that only texts violating the core values and basic tenets of Islam are prohibited. ${ }^{34}$ Like all matters of iğtiha $\bar{d}$, in the absence of uncontested legal texts, opinions multiply, perhaps even develop into varying schools following the many schools of figh.

Art, as al-Kìlānì defines it, is "a wonderful and pleasing expression of the self and of life, characterized by originality and truthfulness, - an expression of human experience in an 'artistic' form, usually in recognizable genre, be it fiction, poem, drama or music"; 35 also, "the end of art is to please, benefit and provoke in order to establish a better society."36 Interestingly, he references his terms for "wonderful" ( $\left.r \bar{a} i^{\prime}\right)$, and "pleasing" (mumtic and imtā $)$ not to an antecedent theory but to Koranic verses that encourage the enjoyment of tayyibāt, good and enjoyable things in life. ${ }^{37}$

Bearing in mind the spiritual significance of art in early civilizations especially in ancient Egypt, and "the pursuit of happiness as the ultimate goal unifying art and religion," al-Kīlānī beckons art to join forces with religion to "realize a society free from hatred, selfishness and jungle law; a society where order prevails." 38 This chaos/order tension confronts the artist with the problem of where on the wide and gradated divide between the real and the ideal one should locate the text and its world; an issue that may clash with the concept of realism if closer to order, and with the appropriate limits on the portrayal of evil if too truthful to reality.

"Islamism" thus stands for the combination of art and, in a broad sense, religion; an orientation delineated as "the religious perspective on man and nature in connection with literary conceptions."39 In al-Kïlāni’s opinion it is not another literary school in the narrow sense of the word like realism, romanticism, existentialism, parnassianism, etc., ${ }^{40}$ for "literature is too large to

33 Ibid., p. 7 and 117.

34 'Imād al-Dīn Hुalīl, al-Ġāyāt al-mustahdafa li-l-adab al-islāmī: muhāwalāt fì l-tanẓ̌ir wa-ldirāsa l-adabiyya, Amman, Dār al-ḍiyā’, 2000, p. 15.

35 Al-Kīlānī, al-Islāmiyya, p. 13.

$36 \quad$ Ibid., p. 14.

$37 \quad$ Kor 7,31 .

38 Al-Kìlānī, al-Islämiyya, p. 28-29.

39 Ibid., p. 47.

40 For his survey of Western schools and approaches to literature, al-Kỉlānī expresses his indebtedness to Muhammad Mandūr (1907-1965), one of the founding fathers of modern 
be circumscribed by local or contingent rules." ${ }^{\text {41 }}$ The broad traits of such an orientation, he goes on to assert while comparing and contrasting it with other approaches all the way, are: first, its positive perception of human nature, importing optimism and life-affirmation, and recognizing moral weakness and failure as of accidental nature. It accentuates the notion that in the ultimate message of Islamic poetics, falsehood, evil, and ugliness stand as mere signs of the absence of good. "Evil has no essence," he says; it substantializes only in the void left by the weakening or disappearance of good; "so long as evil is perceived as a disease, its causes can be efficiently dealt with." ${ }^{2}$ Though this value system generally coincides with Koranic principles, al-Kỉānī's direct source is a lecture by Ṣalāḥ al-Dīn al-Salğūqī (1895-1970), Afghanistan's ambassador to Egypt, on the impact of Islam on science and art delivered at a Cairo conference. ${ }^{43}$

The second trait of this orientation is the amalgamation of the subjective and the objective, the internal and the external, departing from romanticism's world/poet binary as well as from classicism's uncritical mimesis. It bestows a degree of personalized creativity on real life as intervention to "reform and renew"; in other words, it is not a mere echo of the here and now, it conveys reality with a sense of the imagined ideal always hovering in the background, which we might as well interpret as its "agenda." It is this tension that al-Kïlānī opts to capture in the oxymoronic formula of his coinage, "idealistic realism or Islamic realism," as opposed to "dark" naturalism and socialist realism. ${ }^{44}$

Al-Kîlānī further develops his definition in later works, mainly, Madhal ilā l-adab al-islāmì (An Approach to Islamic Literature, 1987) and Hawl al-qișșa l-islämiyya (On Islamic Fiction, 1991) among others. Here he argues that for a literary discourse to convey an Islamic perspective it does not need to be satiated with explicit religious nomenclature or rhetoric, i.e. Koranic verses, Prophetic Traditions, ${ }^{45}$ or with the words "Islam" and "Islamic" in a "clamorous and directly edifying" tone; all sure to damage the "literariness of the text." ${ }^{\text {" }}$ The text may not consciously register anything "Islamic" at all. He explicitly iterates,

Arabic criticism, particularly his al-Adab wa-mad̄āhibuh (1957). Al-Kīlānī, al-Islāmiyya, p. 116.

41 Ibid., p. 47.

42 Ibid., p. 49.

43 Ibid., p. 47-56. Șalāḥ al-Dīn al-Salğūqī published a book on the same subject under the title Ațar al-islām fì l-funūn wa-l-ulūm in 1956.

44 Al-Kīlānī, al-Islāmiyya, p. 53-67.

45 Id., Hawl al-dìn wa-l-dawla, Beirut, Dār al-nafẩis, 1971, p. 57.

46 Id., Madhal ilā l-adab al-islāmī, p. 100. 
It is not necessary to have the word 'Islam' in fiction to be considered Islamic. Islamic fiction may address a social, moral, or political problem from an Islamic perspective without slogans, mottos, or noise. The important thing is for the content to be Islamic, and for the ultimate impression on the mind and the heart, as well as the stance taken, to comply with moral values. ${ }^{47}$

It is exactly what sociocriticism reads in literature: those concealed social values, and the social interests indirectly expressed, as quoted above.

This realignment away from formal preaching and preference of subtlety in the form chosen to convey the author's worldview explain al-Kìlānīs perception of Mahfüz. In 1992 and in a short essay under the title of "Islam in Nağìb Mahfūz' Work" we find citations of several explicatory statements quoted from Maḥūz, all pointing to the latter's attachment to Islam. In one such quotation Mahfūz asserts that his own work "reflects Islamic culture" and that the values of "freedom, social justice, solidarity, and [confidence in] science" he upholds there all issue from his Islamic faith, noting that whoever thinks they are borrowed from the West cannot be familiar with Islamic heritage. In addition, we learn from al-Kīlānì that for five years beginning in 1959 he had frequent discussions with Maḥūz "about art, thought and religion" at what seems to be a literary salon in Cairo. In his view, Mahfūz’ portrayal of immorality is actually expository and deprecating in intention, leading ultimately to alienate and repulse the reader. ${ }^{48}$ It is interesting to ponder on the context of the article, published just after the death threats Maḥūẓ received from extremists. It is al-Kīlānìs attempt to clear up what he believes to be a grave misunderstanding concerning Mạ̣fūz, literature, and Islam.

Three entities in the world of literature can be deduced from al-Kīlānìs theoretical elucidations: the Islamic writer, Islamic literature per se, and the Islamically embraced literary work. Muhammad Iqbal best represents the first. Iqbāl: al-šâ'ir al-țāir (Iqbal: The Revolutionary Poet, 1957) is one of al-Kīlānì's earliest works. ${ }^{49} \mathrm{He}$ also devotes a whole chapter in al-Islämiyy ${ }^{50}$ to the comparison between Iqbal and modern Arab writers, such as Šawqī, al-Rāf ${ }^{\prime} \overline{1}$,

47 Id., Hawl al-qișșa l-islāmiyya, Beirut, Mu’assasat al-risāla, 1991, p. 52-53.

48 Id., al-Islām wa-harakat al-hayā, Beirut, Mu’assasat al-risāla, 1992, p. 196.

49 The book won him the Egyptian Government Award for Biography. Annemarie Schimmel lists al-Kīlānì's study of Iqbāl in the bibliography in her Gabriel's Wing: A Study into the Religious Ideas of Sir Muhammad Iqbal, Leiden, E.J. Brill ("Studies in the history of religions", 6), 1963, p. 396.

"Ma'a l-adab al-islāmī l-ḥadīṭ” (“Concerning Modern Islamic Literature”). 
al-Hakim, and many others whose work occasionally expresses Islamic attitudes and ideas, but unlike Iqbal, they are not totally committed to this orientation. Iqbal, he concludes, is the only one who deserves the appellation of Islamic creative writer, as his work is permeated en masse with the Islamic worldview. ${ }^{51}$ "Islamic literature," on the other hand, refers to those isolated works that convey a specifically Islamic worldview, like the ones produced by modern Arab writers. The third entity, which has already been delineated above, consists of "neutral" works: neither specifically Islamic, nor antithetical to Islam. Aḥmad al-Sā'ì, furthermore, adds another ğāhilì category, "preIslamic," not in the historical sense but in its antithetical-to-the-spirit-of-Islam properties. ${ }^{52}$

Progressing from the ontological to the teleological, one may borrow the socio-critical interrogatives posed by Angenot: what does literature know that other discourses do not, and what can it do that they cannot?53 To ask the same questions about Islamic literature, the reply, inferred from al-Kỉānī and fellow critics 'Imād al-Dīn Halīl and Aḥmad al-Sā̄ì, can be summarized as follows: by default, Islamic literature is supposed to open up to metaphysical and philosophical interpretations and conceptualisations of being (human, divine, and cosmic), and to the historicized narratives of the temporal and spatial world of Islam and the peoples inhabiting it. If the narrativisation is disconnected from the interpretive metaphysics, as is the case with Ğurğī Zaydān's (d. 1914) historical fiction as read by these critics, it will definitely fail to construe the teleology and the spiritual dimensions of its actions; subsequently, literature misses its target of repositioning the recipient in the vicinity of higher ideals. ${ }^{54}$ This integral duality is cognate in spirit with sacred art as demarcated by Martin Lings, where

the Spirit shin[es] from behind a human veil. In other words, it is as a window opening from the particular on to the universal, and while being enshrined in its own age and civilization as eminently typical of a particular period and place, it has at the same time, in virtue of this opening,

\footnotetext{
$51 \quad$ Al-Kīlānī, al-Islāmiyya, p. 94.

52 Aḥmad Bassām al-Sāìi, al-Wāqi ìyya l-islāmiyya fì l-adab wa-l-naqd, Jeddah, Dār al-manāra, 1985 , p. 6 o.

53 Angenot, "What Can Literature Do?," p. 217.

54 Al-Kīlānī, al-Islāmiyya, p. 25, and id., Riḥlatī ma'a l-adab al-islāmī, Beirut, Mu’assasat alrisāla, 1985 , p. 14.
} 
something that is neither of the East nor of the West, nor of any one age more than another. ${ }^{55}$

In his treatise titled al-Fann wa-l-'aqìda (Art and Creed, 1990), Halīl examines some western scholars' views on the quiddity and fundamentals of Islamic art. He agrees with Roger Garaudy's postulation in his Promesses de l'islam (1981), ${ }^{56}$ that, broadly speaking, Islamic art is characterized by: (1) the presence of the transcendental divine, (2) dynamism, as its objective is to bring about change and a state of becoming, (3) the integration of this-worldliness and eschatology, and (4) hypostatisation in real life and in beautiful forms. ${ }^{57}$

\section{Islamic Storytelling}

Qașaș (storytelling) is widely conceded as one of the basic techniques in the Koran; relating numerous prophets' experiences, but always in the mode of "not just history," to borrow a historian's phrase, "but history for"; history written in the interest of some infrascientific aim or vision. ${ }^{58}$ Unlike poetry, storytelling is sanctified as part of the prophet's mission: "Tell them stories so that they may give thought." 59 Though vehemently and repeatedly condemning the attribution of poeticality to its phraseology, the Koran unequivocally declares: "We relate to you the best of stories in what We have revealed of this Koran although you were, before it, among the unaware."60

Epistemologically, the difference between poetry and narration is in the kind of knowledge each generates: to interpret "stories" in the Koranic context as the true histories of former prophets and nations is a pillar of the Muslim creed. ${ }^{61}$ Therefore it is interchangeable with "news." ${ }^{62}$ Poetry, on the other hand, has no truth value per se, and is therefore denounced: "poets,- - [only]

55 Martin Lings, Shakespeare in the Light of Sacred Art, London, George Allen and Unwin, 1966, p. 12.

56 Halīl uses an Arabic translation of the treatise by Dūqān Qarqūt, Beirut, al-Wațan al-'arabī, 1984. See 'Imād al-Dīn Hualīl, al-Fann wa-l-'aqìda, Beirut, Mu’assasat al-risāla, 199o, p. 53 .

57 Ibid., p. 66.

$5^{8}$ Hayden White, Tropics of Discourse: Essays in Cultural Criticism, Baltimore, The John Hopkins University Press, 1978, p. 56.

$59 \operatorname{Kor} 7,176$.

$60 \quad$ Kor 12, 3 .

61 Abū Muhammad al-Ḥusayn b. Mas`ūd al-Bag̉awī, Tafsīr máālim al-tanzūl, ed. Muhammad 'Abd Allāh al-Nimr, Riyadh, Dār Ṭayba, 1989, IV, p. 211.

62 Kor 28,3 . 
the deviators follow them, in every valley roaming, and saying what they do not do;" except "those who believe and do righteous deeds and remember Allah often and defend themselves after they were wronged."63 It is a rebuff against Muhammad's opponents who used to deny his prophecy and brand him as poet. Poetry is contradictorily juxtaposed with prophecy: both demonstrate the power of language, but while prophecy is believed to lead and guide, poetry, deriving strength and fascination primarily from linguistic form, may not. Thus, to attain legitimacy it has to evince faith, truth, and justice, an acquirement of essential commitment. Without meeting this condition, it will function as a purely subjective, often rambling form of knowledge, deprived of the ability to interact with reality. Qașaș is the objective counterpart that lifts knowledge from verbal enchantment to a social, interactive, interfacial platform. Thus, connected with thought and awareness, literature's moral and ethical character is settled for ages to come. ${ }^{64}$ Ibn Rušd (Averroes, d. 595/1198) writes: "The aim of poetry making is not any ad hoc pleasure, the aim is indeed for pleasure to happen through the imaginative representation of virtues." ${ }^{\prime 65}$

The recent debate on poetry and spirituality also centers on epistemological considerations: if both reach for realities beyond appearances, their difference "depends on whether 'the forms of things unknown' are revelations or illusions," which certainly leads to "epistemological insecurity." in the Koranic judgment, this insecurity applies only to the "valley-roaming" poets.

While al-Islāmiyya wa-l-mad̄anhib al-adabiyya presents a tentative attempt at sketching a general perspective on literature, it is in his Hawl al-qișs l-islämiyya that one finds a systematic elucidation of an Islamic conception of fiction. Written in 1992, the little volume recapitulates nearly four decades of fiction writing. Al-Kỉāni confidently reiterates that the Koranic story is the prototype of Islamic fiction: its artistic style, abundant imagery, structure, and methods of characterization are unequalled in the Arabic language. ${ }^{67}$ An Islamic theory of fiction, he asserts, can well be derived from and based on a lucid analysis of

\footnotetext{
63 Ibid., p. 26 and 225-227.

64 For a historical survey of the development of this theory, see Muhammad b. Marrīsī l-Ḥaritīi al-Ittiğāh al-ahlāqū fíl-naqd al-'arabì hattā nihāyat al-qarn al-sābi'al-hiğrī, Jeddah, Dār al-madanī, 1989 .

65 Abū l-Walīd b. Rušd, Talhūṣ Kitāb Arisțūṭālīs fì l-šír, ed. Muḥammad Salīm Sālim, Cairo, al-Mağlis al-a' lā li-l-šu’ūn al-islāmiyya (“Lağnat iḥyā' al-turāta al-islāmī”, 23), 1391/1971 p. 105.

66 Ewan Fernie, "Introduction: Shakespeare, Spirituality and Contemporary Criticism," in Spiritual Shakespeares, ed. Ewan Fernie, London-New York, Routledge ("Accents on Shakespeare"), 2005, p. 1-27 and esp. 4.

67 Al-Kīlānī, Hawl al-qișșa l-islāmiyya, p. 22.
} 
these elements, and he sets out to do just that. Again, this idea has precedence in Sayyid Quṭb’s Kutub wa-šahșiyya àt (Books and Characters, 1947) where he regrets that Arab writers have made no good use of the Koran's "artistic techniques of performance, the finest ever," calling upon them to contemplate this aspect of their holy book. He affirms that though the Koran harnesses its aesthetics to the service of religious teleology, appropriating a similar style would really elevate any literary production to unprecedented levels. ${ }^{68}$ One cannot help comparing this with T.S. Eliot's opposition to any literary utilitisation of holy texts; Eliot warns, "Those who talk of the Bible as a 'monument of English prose' are merely admiring it as a monument over the grave of Christianity." 69

Al-Kìlānì goes on to define Islamic fiction as "the effective well-wrought literary performance" that is both edifying and aesthetically pleasing; aiming to inspire spiritual sublimation, and to be provocative intellectually and emotionally. It serves the moral and ethical purposes of religion, with emphasis on diffusing its quintessential universal values of "justice, fraternity and love."70 The Koranic story is described as a powerful wielder of influence: presenting role models, setting higher ideals, illustrating abstract ideas, stimulating intellectual reflection, debating universal issues, and lending moral support to the faithful. ${ }^{71}$ Thence, any "Islamic" attempt at fiction writing should enact one aspect or more of this model,- -in soul and aesthetics equally. It should aim to project the "Muslim personality" and Muslim civilization and to offset the effects of "cultural and colonial invasion."72 Besides, al-Kīlānī warns that the focus on content should not undermine form, as form is the dividing line between what is literary and what is preaching. ${ }^{73}$

\section{Commitment}

Early in his writing career, and as he launches his first theoretical work, alKìlānī expresses respect for Sartre because of what he sees as his "committed existential position" manifested especially in his anti-colonial stands. He

68 Sayyid Quțb, Kutub wa-šahșiyyāt, Beirut, Dār al-šurūq, 1983, p. 40.

69 Thomas Stearns Eliot, "Religion and Literature," in Selected Prose of T.S. Eliot, ed. Frank Kermode, New York, Harcourt Brace Jovanovich ("Harvest/HBJ book"), 1975, p. 97-106, p. 98 .

70 Al-Kīlānī, Hawl al-qișșa l-islāmiyya, p. 22-23.

71 Ibid., p. 10-17.

$72 \quad$ Ibid., p. 18.

$73 \quad$ Ibid. p. 37. 
praises his philosophy of individual freedom which could be unlimited if one recognized and fulfilled the responsibilities it incurred. ${ }^{74}$ In Paul Starkey's postulation, the "slogan" of iltizām, commitment, came to be used by Arab writers in 1950s echoing the translation of Sartre's engagement; a concept that appealed to the new generation of intellectuals due to the political situation arising after the Second World War and the Palestinian 1948 War. ${ }^{75}$

The concept of commitment itself, though not the nomenclature, seems to be quite familiar to those theorizing about Islamic literature. "In al-Kilani's view," Johann Christoph Bürgel cogitates, "this kind of literature is aiming toward an Islamized form of littérature engagée."76 Al-Kīlānī himself summarizes the idea as "genuine art is a fair means to a noble end."77 Islam's philosophy of art in his argumentation is teleology-based. Art must always be socially engaged, a space where personal self-expression merges and interacts with public concerns, and where literature can and should re-adjust inner and external realities, make virtue possible, and function as moral intervention. ${ }^{78}$ The novel in particular should approach social discourse and, in a suggestive, unobtrusive manner, inspire the moral obligation towards one's inescapable burdens. ${ }^{79}$ Though coming from different premises, such conjectures remind one of those made more recently by another Western critic, Marc Angenot:

$[\mathrm{L}]$ iterature is not alone in its corner... Literature is that discourse which, present in the world, comes and speaks with the "words of the tribe" after all other discourses have said what they'd had to say, especially those discourses about certitude and identity; literature seems to have the mandate to listen to them, to return their echoes, even as it interrogates and confronts them. ${ }^{80}$

Like other socially oriented literary movements, socialist realism or feminism, for example, "Islamic realism" worries most about the matter of "why literature?" more than "what is literature?" In his essay "Why I Write," George Orwell states that a writer is controlled not by ordinary politics, but his starting point

74 Al-Kīlānī, al-Islāmiyya, p. 40-41.

75 Paul Starkey, Modern Arabic Literature, Edinburgh, Edinburgh University Press (“The New Edinburgh Islamic Surveys"), 2006, p. 125-126.

76 Bürgel, "Islam Reflected in the Contemporary Literature of Muslim Peoples," p. 827.

77 Al-Kīlānī, al-Islāmiyya, p. 16.

78 Ibid., p. 64-66.

79 Al-Kīlānī, Madhal ilā l-adab al-islāmì, p. 57.

$80 \quad$ Angenot, "What Can Literature Do?," p. 223. Original italics. 
will be a grave sense of injustice, or a huge lie that must be exposed. His own writing, he asserts, has been to a great extent determined by the historical moment in which he finds himself. ${ }^{81}$ Al-Kīlānī shares this active response to the chaotic around. He sees the word as an act of responsibility to be borne by the originator and the receiver. ${ }^{82}$ In his explication in Madhal ilā l-adab al-islāmī, he designates it a "prophetic," reformative role combining the metaphysical with the social and the aesthetic. ${ }^{83}$ Commitment (iltizām) occupies a considerable space in his theoretical work. We find him quoting the Arab theologian and litterateur al-Ğāhiz (d. 255/868-869) who assigns the reformation of the world and the reconstruction of the individual as the most important functions of literature. ${ }^{84}$

Al-Kïlānì sees many injustices oppressing his world that he, as a writer, must react to. At the beginning of his fourth novel Layl al-hațāya (The Night of Sins, 1960), and in a dedicatory note to "those lost in the wilderness," probably among his implied readers, he throws some light on the surrounding social ills causally connecting them to sin: "In the shadow of fear, in the lap of poverty, and on the shores of repression, deprivation, anxiety, together with selfishness and vanity, wrongdoing grows, sin is born, and the timeless values vanish." 85 This resonates of the rhetoric of political remonstration, especially if located in its immediate context: a country in a revolutionary mood when even the title he chooses for his study of Muhammad Iqbal is The Revolutionary Poet.

To go back to more of Angenot's pivotal queries: "What does literature do and [...] what can literature do?" which, in his opinion, must be distinguished from the question "What can literature be used for?"- an interrogation leading to the meaning and nature of commitment. Al-Kìlānī's thoughts on the subject diverge from the blatantly ideological. In his Madhal, literature is described as

a living experience bringing together originator and receiver,- some kind of intense dialogue and rich interaction. Such life experience in an artistic form would appear fresh and exciting, offering insights into the mystifications of our public life and complex relations, endowing our existence with knowledge and joy. It is not true that the aesthetic effect is all there is to it, for it is deeply connected with our minds and

81 George Orwell, Why I Write, London, Penguin, 2004, p. 4-8.

82 Al-Kìlānī, Madhal ilā l-adab al-islāmī, p. 30.

83 Ibid., p. 33-36.

84 Ibid., p. 46.

85 Id., Layl al- ḩațāyā, Damascus, Dār al-fikr, 196o, p. 5 . 
mental activities, our emotions and their turnings, our thoughts and their development. ${ }^{86}$

Objecting to "literature turned into political bulletins, partisan discourse, or denigrated into some leader's propaganda," ${ }^{87}$ he admits that writing can be a powerful source of provocation and agitation even when not overtly so. In his semi-autobiographical novel Fì l-zaläm (In the Darkness, 1959), the protagonist, a village schoolteacher, extols the historical impact of certain writers:

I wish you heard Officer Faraḥāt al-Surūğ̄̄'s talk about Rousseau, Voltaire and others who prepared the way for the French Revolution; and Gorki and Tolstoy and what they offered to the Socialist Revolution in Russia. Those were the vanguard of the struggle, and the light that showed the path to freedom fighters. ${ }^{88}$

Naturally, al-Kīlānī is keenly aware of the pitfalls of what he calls ilzām (external or public enforcement) to distinguish it from iltizām. It is with ilzām, disguised as commitment, that totalitarian regimes manipulate creative minds; ${ }^{89}$ while the right thing is "inner" or "personal" commitment, manifested in individual and authentic choices, where people articulate what transpires in their minds, hearts and souls, and express their own philosophy of life. Commitment, in alKìlānì's conception, is not the antithesis or the negation of freedom, ${ }^{90}$ it brings order to that freedom and steers the creative impulse into becoming a source of happiness, not of chaos and madness. ${ }^{91}$ The golden mean in this equation is to achieve equilibrium between responsibility towards society, being the writer's target, and towards one's own self, as the object of discipline; - a challenge that thrusts the writer into a continuous state of engagement. ${ }^{92}$

Although socialist realism, al-Kīlānī believes, has some positive aspects, tendentious literature, adab muwağğah, such as the extreme indoctrination practiced in Communist Russia that "led to the stifling of creativity by depriving artists of their freedom" is the worst kind of using (and abusing) literature:

\footnotetext{
86 Id., Madḩal ilā l-adab al-islāmī, p. 26.

87 Ibid., p. 28.

88 Id., Fù l-z̧alām, Beirut, Mu’assasat al-risāla, 1980, p. 49.

89 Id., Madhal ilā l-adab al-islāmī, p. 78.

9o Ibid., p. 81.

91 Ibid., p. 84; id., al-Islāmiyya, p. 30.

92 Id., Madhal ilā l-adab al-islāmī, p. 77-80.
} 
Its error issues from the impairment of freedom due to its narrow indoctrination that deems any dissidence or criticism an act of treason and disobedience. It also has to do with the new, aberrant values that prevail in the new society, which destroy family life [...] and pulverize spiritual values. $^{93}$

To recap, the commitment al-Kīlānī envisages is not a reaction to expedient, local or temporary crises, or a tool serving an economic doctrine; ${ }^{94}$ it signifies adherence to the broad bases of the faith and to universal ideals, with the mind completely liberated from fear, desire, greed or tyranny. ${ }^{95}$

\section{Al-Kīlānī the Storyteller}

It was in 1957, in one of Nasser's prisons, that al-Kīlānī, a fourth-year medical student at Cairo University, made his debut as a novelist. In his cell, literary pursuit was the best way to cope with the horrors he witnessed and personally experienced there. Along with many members of the Brotherhood, he was detained in 1955 and sentenced to ten years in prison but was released three years later, only to be rearrested in 1965 and incarcerated for almost two more years; charged in both cases with conspiracy to overthrow the government. ${ }^{96}$

Ironically, while still in prison, he received several government awards for literature; two of the 1957 awards: one for his first novel al-Taríq al-țawil (The Long Road) and the other for his study of Muhammad Iqbal. ${ }^{97}$ Two more novels, Fì l-zalām (1959) and al-Yawm al-maw'ūd (The Promised Day, 1959?), also won him government awards, including that of the Higher Council for Arts and Literature. More surprising and of special significance was the Ministry of Education's decision in 1959 to include two of his novels, while still a political prisoner, in the national school curricula. ${ }^{98}$

93 Id., al-Islāmiyya, p. 43-44.

94 Ibid., p. 46.

95 Id., Madhal ilā l-adab al-islāmī, p. 83.

96 Id., Lamahāat min hayātī, Beirut, Mu’assasat al-risāla, 1985, II, p. 189-272; id., Rị̣latī̄, p. 230. For more information on the "special courts" set by the military junta, see Yoram Meita, Revolutionary Justice: Special Courts and the Formation of Republican Egypt, New York, Oxford University Press, 2017.

97 Al-Kīlānī, Riḥlatī, p. 24. Here al-Kīlānī lists the many prizes that he was awarded by the government and some civil institutions in the early years of his writing career and while still seen by the regime as a member of the opposition.

$98 \quad$ Ibid., p. 29. 
The traumatic prison experience, portrayed graphically in his memoirs, remains a recurring motif and a metaphor for tyranny in most of his work. 99 "My novel, Layl al-'abid (The Slaves' Night) depicts prison life, [...] aiming basically to represent tyrannical rule through the character of the prison warden, while prisoners stand for the nation under oppression."100 Prison horror, as Paul Starkey indicates, becomes a frequent subject in contemporary Egyptian writing; sometimes, as in the case of Șun' Allāh Ibrāhīm, it transposes "the rootlessness and meaninglessness of life as reflected in much post-Second World War European fiction [...] to the oppressive, post-revolutionary regime of contemporary Nasserist Cairo."101

Whether because of traumatic experience, persistent idealism, or for its own inherent value, cultural and political freedom occupies a central position in his worldview as painstakingly explicated in Rihlatì ma'a l-adab (My Journey with Literature, 1985).102 "It is the foundation of righteous life,"103 he asserts, introducing the idea of "no religion without freedom" for faith begins with free choice. ${ }^{104}$ In his 'Amäliqat al-šimāl (Giants of the North, 1974), a novel set in the Nigerian Biafran War (1967-1970), all that the people yearn for "is an atmosphere of real freedom of speech, and not a [Muslim] ruler who coerces people into conversion. It seems freedom has begun; that by itself is a great victory for the faithful." Freedom to al-Kīlānī comes above religious considerations: "Ya'qūb John was a good son for the Muslim Hausa, despite the fact that harsh circumstances made him turn to the Christian faith." He gave his people freedom, "What more would callers to Islam want?"105

The early encounter with Iqbal's complex thought with its synthesis of traditionally opposed streams of knowledge: Sufism, western and eastern philosophies, and theology, and where poetry and politics harmoniously interrelate, forms a turning point in al-Kỉlāni’s life. "Iqbal," he writes, quoting the words of an unnamed Hindu leader, "lighted the lamp at the Muslim's door, but he did not keep its light from non-Muslims. Everybody could benefit from the light of that lamp."106 It is under Iqbal's influence that al-Kîlānī adopts literature

99 In the early sixties, al-Kīlānī published al-Muğtama` al-marị̄ (The Sick Society, 1964?), an empirical study of prisons in Egypt up to 1963. It won the Ministry of Education's Award for Sociology and Philosophy.

100 Al-Kīlānī, Rihlatī, p. 27.

101 Starkey, Modern Arabic Literature, p. 141.

102 Ibid., p. 105-108.

103 Ibid., p. 26.

104 Ibid., p. 108.

105 Al-Kīlānī, 'Amāliqat al-šimāl, Cairo, Dār al-ṣaḥwa ("Riwāyāt islāmiyya mu'āṣira”), 2012, p. 191.

106 Id., Iqbāl: al-šā ir al-tâ̄ir, Beirut, Mu’assasat al-risāla, 1980, p. 12. 
as a second (or first?) career, ${ }^{107}$ finding in it, as Iqbal has done with poetry, the best way to express his Weltanschauung. One can also surmise that the impact of Iqbal's philosophy of the self has prompted al-Kìlānī's intellectual independence, even from the Muslim Brotherhood, for he discovers that Iqbal's thought "remains free and freedom-oriented, critical, dialectical and analytic, [...] resulting in a new philosophy and Weltanschauung."108

For the space of his first novel al-Kïlāni goes to the Second World War and to the autobiographical world of his village Širšăba, to which he kept returning in a Faulknerian style. Though far removed in the countryside, Širšāba feels the pulse of history and is involved in it, epitomizing an authenticity of Egypt. Unaware of literary labels and genres whether Islamic or otherwise, his early novels reproduce the village discourse and conservative worldview. Reflecting on his debut many years later, he writes,

The village traditions are the closest to true Islam [...] As a result my writings were unintentionally Islamic.

My primary goal was to portray the poverty, misery, ignorance, disease, injustice and corruption the people suffered from because of the war, the despotic rulers, colonisation, and the lack of noble human values in Western civilisation. [...] That novel [al-Tarīq al-țawill] is an expression of my own bitter experience. ${ }^{109}$

His second novel, $F \bar{l} l$-zaläm captures Egypt's struggle against the corrupt monarchy and the British mandate in the tumultuous period 1947-1952, with events preceding and leading to the army's $195^{2}$ seizure of power. On the surface, it appears like any mainstream fiction, but scrutiny of the text and its immediate context reveals layers of complexity. Firstly, the optimistic note on which the novel concludes creates a problem for the observer, for its writer is actually a political prisoner of the new regime, the object of that optimism. In the last scene, the political prisoners of the monarchy are about to be released at the very beginning of the military takeover:

Farīd and his companions felt that the huge darkness that engulfed them in their narrow cell was about to recede as it had done from over the heart of the homeland. Al-Basțawīsī [the Azharite šayh] could not control his joy; he climbed the iron bars on the cell window and shouted as

\footnotetext{
107 Id., Madḩal ilā l-adab al-islāmī, p. 22; id., Riḥlatī, p. 35-36.

108 Id., Iqbāl, p. 23.

109 Id., Rị̂latī, p. 22-23.
} 
loud as he could slogans against tyranny, the enemies of freedom, and the colonisers. ${ }^{110}$

These two novels seem to hail the $195^{2}$ army takeover as a revolution that would bring salvation and freedom; a problematic feat indeed; for the change proves disastrous for the author and the thought he represents. By the time the novels are published, the military regime, as depicted in al-Kilann's later novels, has already shown an iron fist more oppressive than the monarchy's. Many members of the Brotherhood have been either executed or incarcerated; while he himself is writing, three years after the "revolution," from behind bars. ${ }^{111}$

The irony and the paradoxical situation have confounded his critics, not knowing what to make of it: what precisely is al-Kīlān's message? The interrogation of the text is justified by the edifying function he himself assigns for literature, that the word is an ethically accountable act. In addition, the semi-biographical nature of this particular novel, $F \grave{l} l$-zalām, bestows upon it a commentarial status that interprets actual political events fresh in the reader's mind. One Islamic critic finds it incomprehensible that al-Kìlānī, "with the whiplash wounds still fresh on his back, and the spilled blood and the torn bodies vivid in his mind" is the one who promotes such ideas of hope and salvation. He goes further to throw doubts on al-Kilāni’s motive, whether it is greed or fear, ${ }^{112}$ with a suggestion of "eagerness to please and desire for popularity.113

Yet, observable too is the ambiguity in al-Kïlānì's handling of the matter: $F \bar{l}$ l-zaläm lingers in time at the threshold of the new era, leaving it in anticipation as an unexplored territory. The author's introductory note to the novel dwells on the people's hopes, not their fulfillment:

The period in which the events of this novel of resistance and romance took place, 1947-1952, was a time of confusion in ethical values and principles; a time of perplexity and anxiety,-moral, social and emotional. But, the great obvious truth was that the people were determined to gain

\footnotetext{
110 Id., Fù l-zalām, p. 259.

111 Al-Kīlānī was actually imprisoned twice, first in 1955 for three and a half years, then in 1960 for a year and a half. See id., Rị̣latī, p. 230-231.

112 Muḥammad Ḥasan Brīğš, Dirāsāt fì l-qișșa l-islāmiyya l-mu'āṣira: ma'a 'arḍ li-'adad min riwāyāàt Nağīb al-Kïlānī, Beirut, Mu’assasat al-risāla, 1994, p. 43.

113 Id., "Naḥwa adab islāmī: ma‘a riwāyāt islāmiyya mucāṣira li-l-doktor Nağīb al-Kīlān̄̄," Mağallat al-muğtamac, 224 (1974); reprinted in al-Kīlānī, Rị̣latī, p. 162-166.
} 
victory; they walked every path anxiously searching for the light,-—for a better life. They could not live 'in darkness' anymore. ${ }^{114}$

Besides, the depiction of the horrific torture scenes in the novel seems to reflect, in conscious displacement, first-hand experience camouflaged as practices of the pre-1952 regime.

Al-Kỉlānì's own belated response to such criticism comes in his autobiographical reflections in Rihlatī ma'a l-adab (1985), described by Malti-Douglas as "a fascinating work, more personal in nature, and conceived as a journey."115 There he cites some well-known critics and literary figures who have written serious and positive reviews of his fiction; among them Rağāa al-Naqqāš, Nağīb Maḥfūz, Muḥammad Quṭb, and 'Alī Aḥmad Bākatīir. Discussing his critics' views, he mentions the factors that have had an immediate impact on his early fiction (comprising eight novels and four short story collections so far), such as the sinister circumstances of his anonymous entry into those literary competitions from incarceration, the ruthless censorship and the anti-religious indoctrination prevalent under the military regime. ${ }^{116}$

The crisis with the Egyptian government continues even after his release: a television series based on one of his apolitical novels is banned by the Egyptian government because the hero parodies "certain medical doctors." ${ }^{117}$ Feeling the need for intellectual emancipation, he begins his diaspora in the Gulf in 1968, ${ }^{118}$ leaving his homeland and the "intellectual terrorism" reigning therein, ${ }^{119}$ in search for a breathing space where to speak one's mind is not a criminal offence. Once out of Egypt, it becomes possible to touch on the history of the present: one of his characters, a servant,

having served in [pre-revolution] palaces of princes and the royal entourage, saw many like 'Ațwa Beg [the post-1952 prison warden]. Nothing has changed, the same kind of people, all from the old regime itself. Today is like yesterday, and tomorrow is not likely to be any different, if not worse. ${ }^{120}$

\footnotetext{
114 Id., Fì l-zaläm, p. 5 .

115 Malti-Douglas, Medicines of the Soul, p. 6-7.

116 Al-Kīlānī, Riḥlatī, p. 23-24 and 54.

117 Ibid., p. 54. Al-Kīlānī adds that it was screened on several Arab television channels outside Egypt.

118 Ibid., p. 231.

119 Ibid., p. 40.

120 Id., Rị̣la ilā Llāh: qișsat al-iḩwān al-musliminn al-dāmiya, Cairo, Dār al-ṣaḥwa, 2012, p. 60.
} 
Also in Riğăl wa-diāa (Men and Wolves), the intelligence officer ironically defends Nasser by comparing him to Stalin,

"who killed millions of the enemies of the revolution, then defeated the Germans." He continues, "Russia now is one of the two super powers."

After reflecting for a moment, [his sister, a medical doctor], asks, "Is it enough to manufacture terrible weaponry, provide bread, and achieve technological progress to be happy?"

"What else would a human being want in this age, doctor?"

"Happiness, dignity, freedom." ${ }^{121}$

One strategy to evade the heavy-handed censorship is the escape to history. While in jail, al-Kīlānī publishes Ṭalā’’ al-fağr (Dawn Break), his debut in historical novel set against the background of the 1807 British campaign in Egypt known as the Fraser Expedition. Al-Kīlānī's reconstruction of plots from history centres on historical knots, significant moments of confrontation with foreign invasion, as well as of internal political unrest; not just in Egypt but also in the wider geography of Islam; such as Indonesia and Bosnia. "When burdened with pain and crushed by tyranny," he writes in the introduction to his Iqbāl: al-šā ir al-ta ẩir, "people dream of the past, of their glorious history, trying to find comfort, consolation, hope, and the possible motivation to push them forward."122 Some of the titles he chooses strongly remind us of Ğurğ̄ Zaydān;

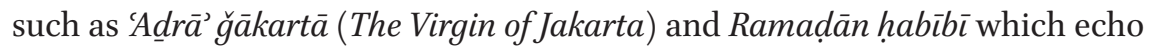
Zaydān's 'Ad dră' Qurayš (The Virgin of Qurayš) and 17 Ramaḍān; a point that can be interpreted as a deliberate, "corrective" move, considering al-Kïlānìs criticism of Zaydān mentioned above.

\section{Islamic Realism}

Realism, according to al-Kīlānī does not imply a writer gets totally entangled in his "here and now"; rather, in order to be able to leverage social change, a writer should maintain an intellectually independent, yet ahierarchical position in his world. ${ }^{123}$ It is the kind of tension to be expected in an "idealistic realism, or Islamic realism," a term that signifies on one side the idealistic-Islamic synonymy and, and on the other, the assumption that in the combination of

\footnotetext{
121 Id., Riǧāl wa-diāab, Cairo, Dār al-ṣaḥwa, 2012, p. 146.

122 Id., Iqbāl, p. 8.

123 Id., Madhal ilā l-adab al-islāmī, p. 115-118.
} 
idealism and realism literature is allowed to portray life and improve on it, with a utopian tint perhaps; thus, the artist becomes "like the link connecting earth and heaven."124 Fredric Jameson asserts that "at best Utopia can serve the negative purpose of making us more aware of our mental and ideological imprisonment,"125 which can be partially applied here to the "idealist realism" concept, pinpointing its double functionality. For, in addition to this negative effect, it conveys the positive promise, perhaps the "messianic promise" of a perfect reality Derrida vouches for:

Unlike Marx's utopia, Derrida's is not the communist fruition of teleological history but the 'messianic promise' of a perfect democracy, a state of perfect responsibility to all that will never be realised. But, far from being hopeless, this unrealisable dream - life beyond life, life against life, but always in life and for life'-elevates human beings above mere biology, supplying the ecstatic, aspirational energy of human history. ${ }^{126}$

Also, like George Orwell (d. 1950), al-Kìlānī wants the author, to borrow Orwell's phrase, "to push the world in a certain direction" and "to alter other people's idea of the kind of society that they should strive after."127 Idealistic or Islamic realism, al-Kïlānī explains, captures, provokes and enhances the tension between actual experience and the dreams and the yearnings for an imagined ideal. ${ }^{128}$ If Angenot considers literature as entelechy in the Aristotelian sense, ${ }^{129}$ al-Kīlānī sees it as entelechy in the sense of forming a force not just inscribing, but also driving society towards the fulfillment of its desired form.

"Islamic realism" as a term has become since then the hallmark of Islamic theorization on literature. It is perceived as different from "pessimistic Western realism," what al-Kỉlānī refers to as "dark realism," in which evil gets the upper hand and human and moral principles disappear or lose value. ${ }^{130}$ Muhammad Mandūr, al-Kīlānī's source, points out the considerable confusion surrounding the term wäqiciyya in Arabic, a matter he tries to sort out in a lengthy exposition

\footnotetext{
124 Id., al-Islāmiyya, p. 53-67.

125 Fredric Jameson, Archaeologies of the Future: The Desire Called Utopia and Other Science Fiction, London, Verso, 2005, p. xiii.

126 Ewan Fernie, "The Last Act: Presentism, Spirituality and the Politics of Hamlet," in Spiritual Shakespeares, p. 186-211 and esp. p. 194.

127 Orwell, Why, p. 4-8.

128 Al-Kīlānī, al-Islāmiyya, p. 66-67.

129 Angenot, "What Can Literature Do?," p. 221.

130 Al-Kīlānī, al-Islāmiyya, p. 31-33.
} 
of French realism as represented by Balzac, where reality is portrayed as ultimately hopelessly dark and sinister. ${ }^{131}$ In opposition to this, socialist realism, and al-Kïlānī appreciatively quotes Mandūr's definition of the term as edifying literature, advocates belief in the positive goodness of human nature, ${ }^{132}$ which indicates some intersection with Islamic realism.

However, when it comes to application, some problems arise, such as: how realistic can this realism be? How detailed can a depiction of an intolerable reality be if changing it is the ultimate goal of the creative effort? How far can the artist/writer go in drawing scenes of sin, crime, violence, sex, illicit desire, and all the vices in the world, and what is believed to be "anti-Islamic" elements? How much room is allowed, if any, for the author's interference,-manipulation of characters as mouthpieces to instill one's ideals? Obviously, it becomes a matter of contriving a balance between the writer's freedom to explore and represent different aspects of human experience on one side and his commitment to ethical, social, and artistic ideals on the other,- - a matter still in a state of flux in the context of Islamic literature.

Such quandaries are discussed in al-Kïlāni’s Riḥlatĩ ${ }^{133}$ and Hawl al-qișșa where he distinguishes himself from other Islamic writers by insisting on the need also to portray different forms of evil and villainy in order "to give form to the conflict" between good and evil, and enable the receiver to make a learned and free choice, ${ }^{134}$ rationalising this view as: "When human weakness is portrayed, it is in order for us to understand and cure it, not to provide justification and excuses." ${ }^{135}$ To support this argument he cites Koranic stories, especially that of Prophet Joseph, a series of episodes of human frailties and redemption. Consequently, the characters he chooses represent a wide spectrum of good and evil, transcending class, gender, religion and ethnicity. In Țalā' $\iota^{\prime} a l-f a g ̆ r$, for instance, Rose, the Armenian Christian girl, does not heed the conspiratorial role her father designs for her and acts according to her own free conscience; which makes her morally a fair match for Ibrāhīm, the conservative Muslim leader, her reluctant husband.

Reporting controversial ideas too gives a polyphonic quality to al-Kỉānī's fiction, though sometimes misunderstood and harshly judged by fellow Islamic critics who perceive it, especially in $R a^{3} s$ al-šayțān (The Devil's Head) and $F \bar{\imath}$

\footnotetext{
131 Muḥammad Mandūr, al-Adab wa-mad̄āhibuhu, Cairo, Nahḍat Miṣr, 1957, p. 9o-95.

132 Ibid., p. 112.

133 Al-Kīlānī, Riḥlatī, p. 50.

134 Id., Hawl al-qișsa l-islāmiyya, p. 51-52.

135 Ibid., p. 5.
} 
l-zaläm, as instances of immorality and breach of Islamic propriety. The critics imply that the author's message should be more straightforward and his authority more visible. ${ }^{136}$ In another novel, al-Nidāa al-hălid (The Eternal Call, 1962), al-Kìlānī, they argue, has not made corrective comments on the errant behavior of his female characters, or the "un-Islamic" ideas those characters advocate such as Qāsim Amīn's emancipatory views on women. ${ }^{137}$ But to be fair to al-Kīlānī, one must mention that he usually sets the balance by providing a character, - a father or a Sufi šayh, or even a picture of the archetypal reformist Ğamāl al-Dīn al-Afğānī (d. 1897) on a wall in the heroine's room ${ }^{138}$ to dialogically counter such "impious" elements.

A more serious transgression, from the critics' point of view, is the way his protagonist in Ra's al-šaytān, a journalist with a doctorate in law from France and a leader of a resistance organization, allows women to bait British soldiers, a totally unacceptable means of resisting occupation. ${ }^{139}$ In an untypically defiant reply, al-Kïlānī argues that if certain portrayals in his fiction go against Islamic principles, "So what? They do exist among us, and this is the malevolence we need to recognize and try to change." $140 \mathrm{He}$ expects the reader/critic to discover the deep meaning of the text and to realize that such characters are not set up as role models; depicting them is no more than an honest portrayal in this case of Egypt of the 1930s, when any major presence or influence of the Islamic movement was hardly noticeable. ${ }^{141}$ The character of Dr Diyā' alDīn in particular, having lived in France for some time, returns with a mindset smacking more of Marxism than Islam or of a curious amalgamation of the two. Addressing his followers, he says,

136 Of these critics, al-Kīlānī mentions 'Abd al-Qādir al-Qițț. Al-Kīlānī, Riḥlatī, p. 52. See also 'Abd Allāh b. Șāliḥ al-'Arrīn̄i, al-Ittiḡāh al-islāmī fı̀ a'māl Nağīb al-Külānī l-qașașiyya, Riyadh, Dār kunūz Išbīliya, 2004, p. 146.

137 Al-Kīlānī, al-Nidā’ al-ȟălid, Beirut, Mu’assasat al-risāla, 1981, p. 181 and 199-200.

138 Id., Ra's al-šaytānn, Beirut, Mu’assasat al-risāla, 1979, p. 229. Al-Kīlānī points out that this particular novel belongs to his early œuvre as it was first published in Cairo by publisher Ḥamdī Muștafā in the early 196os, adding that the 1979 Beirut edition was actually a third print, a fact omitted in the new edition, leaving readers under the impression that it was written in 1979. Al-Kīlānī, Riḥlatī, p. 51. It actually appears in the list of works by the same author at the end of a book by al-Kīlānī: al-Ṭariq ilà ttiḥād islāmì, Tripoli, Maktabat al-nūr, 1962.

139 Id., Ra's al-šayțān, p. 134-135.

140 Id., Rihlatī, p. 97.

141 Ibid., p. 51. 


\section{Friends!}

The King, Șidqi [the then Egyptian prime minister], the Pashas, the capital owners, the [British] High Commissioner and all their puppets, are but aliases of the vicious cancer of imperialism. It is the source of evil, [...] Satan's head, rather. [...] We dream of freedom, my friends, dreams that cannot be realized without a high price. [...] We hate violence and bloodshed; we love peace, but how can we deal with those who have robbed us of peace, spilled our blood, and deprived us of love, life, hope and freedom? ${ }^{142}$

The phraseology in particular is not exactly the usual religious rhetoric; his terms of endearment when addressing the comrade he loves are "Jeanne d'Arc, my dear saint;" ${ }^{143}$ so, casting him as protagonist, as a character that might think and act differently from its maker illustrates the significant stride al-Kīlānī has taken to actualize his own sense of realistic representation, challenging at the same time the horizons of expectations of his Islamic readers. While those critics demand that the "Islamic writer suggest that such and such act is wrong and not Islamic,"144 al-Kīlāni warns against preaching, contending that the task of literature is to be provocative in the broadest sense. He reasserts that "a rhetorical, hat $\bar{a} b \bar{b}$, tone is not less dangerous than a bare factual style, for the reader would find the author's intrusion [...] bothersome, obstructing the appreciation and the pleasure of the work of art." ${ }^{145}$ What we readers need to listen to is the voice of the text itself, even then, as Fredric Jameson puts it, "in narrative analysis, what is most revealing is not what is said, but what cannot be said, what does not register on the narrative apparatus."146

Another piece of advice al-Kīlānī throws back is the necessity for criticism to take into consideration the natural bend of a writer's development and how this evolution materializes in his work. It is the mix up of chronology that has led to a "discordant dilemma" in his career: ${ }^{147}$ those particular novels, he comments, have been written prior to his formulating any perspectives on literature; so they should not be retroactively judged by that formulation; albeit, the religious elements are spontaneous there because "our [social] environment is generally Islamic," he goes on to explicate, "in my first novel, al-Ṭariq al-țawìl,

\footnotetext{
142 Id., Ra’s al-šayțān, p. 69.

143 Ibid., p. 135.

144 'Arrīn̄ī, al-Ittiğāăh, p. 73-75.

145 Al-Kīlānī, Taḥta rāyat al-islām, Beirut, Mu’assasat al-risāla, 1982, p. 101.

146 Jameson, Archaeologies, p. xiii.

147 Al-Kīlānī, Riḥlatī, p. 46-47.
} 
you sense this through the father's character,- -his speech and actions; especially in his prayer, and the way he faces the consecutive calamities befalling him." ${ }^{148}$ It is a disguise the author must wear in order for the receiver to accept his presence in the text.

Consequently, describing this realism as Islamic does not reposition reality in a utopic space or, worse, bring it under authorial tyranny. In a study on woman in al-Kìlānīs novels (2007) the present author addresses the problematic issue of "how authoritative can the author be? Is it always his voice reverberating through the agency of his characters? Or of his narrators?"149 $\mathrm{Al}-$ Kilāni’s practice is sometimes best visualized in a framework of Bakhtin's heteroglossia. For example, a character in al-Taríq al-tawìl contemplates the new state of affairs in Egypt, saying, "it is a source of satisfaction, my son, that, for the first time, Egypt is governed by rulers Egyptian by blood, by nurturing and by feelings. A dream comes true. We have our nationhood and dignity back."150

Commenting on the display of this "narrow" nationalistic attitude in a novel by an "Islamic novelist," a critic condemns what he describes as the "revival of the "Pharaonic spirit"'151 in the total rejection of all historical rulers, expecting from al-Kìlānī a less neutral stance. He ought to have, somehow, inserted the traditional stance of the Islamic movement that faith transcends nationalism, meaning that the early Muslim rulers of Egypt, companions of the Prophet arriving from Arabia are an exception. Al-Kỉlānī rebuffs the censure in a generalized statement: "Scientific, historical, and artistic integrity," he rejoins, "makes the inclusion of slogans of nationalism and Arabism imperative; the characters opposing the monarchy, feudalism and political corruption during that period are not strictly Islamic."152

Class conflict is another swerve al-Kìlānī ventures, diverging from the conception of Islamic realism expounded by fellow critics such as Hilmī Muhammad al-Q⿱ācu $\mathrm{u}$. While they try to distance themselves from Marxist strategies and emphases on economic factors, al-Kïlānī is adopting similar strategies as integral to the social engagement of Islamic literature. At the beginning of his


Realism in Nağib al-Kïlānìs Novels, 1996), al-Qā̄ūd asserts that "Islamic real-

\footnotetext{
148 Ibid., p. 26.

149 Samira al-Khawaldeh, "al-Mar’a fì riwāyāt Nağīb al-Kīlānī," in Adab al-mar'a, Riyadh, Maktabat al-'Ubaykān, 2007, p. 63-101.

$15^{0}$ Al-Kīlānī, al-Ṭarīq al-țawùl, Beirut, Mu’assasat al-risāla, 1977, p. 299.

$15^{1}$ Brìgšs, Dirāsāt, p. 43.

$15^{2}$ Al-Kīlānī, Riḥlatī, p. 51.
} 
ism differs essentially from European realism (critical and naturalistic), and (Marxist) socialist realism, and in spite of the fact that principles of artistic form and content may be considered common to all," such as revisionism, Islamic realism is far from any conflictual, deterministic propensities.

[Islamic realism] issues from an Islamic perception that is always fair: no exaggeration, no inflation, and no bias against [people with] different loyalties. It does not promote class conflict, like socialist realism does. [...] [Islamic realism] derives its substance from social life and presentday problems in general; choosing characters from all social strata, for it believes that good and evil are not the sole obtainment of one particular class, but inherent in the human psyche. [...] [H] uman beings can be good or bad by choice, while other concurrent factors may only influence that choice. ${ }^{153}$

Al-Kīlānī does not see eye to eye with Q ấūd's view on the provocative role of literature. An acute awareness of the injustice in the prevalent class division in Egypt and of the extreme and devastating effects of poverty permeates his work, especially in its early phase. On one side, he is guided by the religious ethics of justice and equality, and on the other, by the novelist's need to particularize "the substance of public life" he is immersed in, and to have its demons named. There is also the impending communist threat that cannot be overlooked. In $R a^{\prime}$ s al-šayțān the editor-in-chief refuses to publish the heroine's report, explaining,

Your report on the workers and trade unions incites rebellion. The word "workers" by itself is enough to stigmatize you as radical and anarchist. Do not forget, my dear, that in this country there is a king, a government, England, and capital; you understand that capital owners can dissolve the government and close down an inconsequential newspaper like ours. [...] Șidqī Pasha [the prime minister] has abolished the 1923 constitution; no one now can even think of impeaching cabinet ministers. ${ }^{154}$

Still, al-Qāeūu, al-Kīlānī and similar critics have much in common with Georg Lukács (d. 1971) — though his name never comes up -, primarily when it comes

\footnotetext{
153 Ḥilmī Muḥammad al-Qāāūd, al-Wāqiìyya l-islāmiyya fì riwwāyāt Nağīb al-Külānī, Amman, Dār al-bašìr, 1996, p. 15 .

154 Al-Kīlānī, Ra’s al-šayțān, p. 28-29.
} 
to the objection to the elitism and the obscurity of modernism, as well as its extreme ambiguity and undecipherable symbolism, all of which may hinder author-reader rapport.

Al-Kìlānì himself is quite impressed by the impact of Maxim Gorki's The Mother on his classmates at Cairo University (prior to his writing career), and by the high literary standards such an ideological work has attained, that he wishes for something similar to serve the goals of the Islamic movement. ${ }^{155}$ Culture as power producing imagined forms and hypostatisations of abstract beliefs that can reach everyday man is a concept Islamists have not demonstratively procured till then. It must be added here that Gorki, Dostoyevsky, Tolstoy, and Sartre (the last with reservations) have all exerted some influence on al-Kīlānī's writing and sense of commitment as he himself declares in a 1971 interview. 156

To such influences can be attributed the types of villains al-Kilānī portrays especially in his early novels, coming mostly from the upper class,- - the Pashas, the landowners, and the wealthy, who happen to be at the same time the politicians and the holders of power in the country. Nevertheless, al-Kilānì sees that realism is at its best when the fictionalization relates to the writer's own immediate environment; so, when it comes to the redistribution of land among the fellahin, it is the religious leader Šayh 'Ināba who calls for it. Another theme common to communists and al-Kîlānì is the constant appeal to the consciousness of the masses, and to popular uprisings, which can be equally interpreted on his behalf as both a counter-communist gesture and an inherent democratic tendency. In al-Nidāa al-hălid, i.e. the call of freedom, the narrator testifies, "The British understood that the revolt [of 1919] was not a revolt of leaders, or political parties, but of the whole nation." ${ }^{157}$ And in al-Yawm al-maw' $\bar{u} d$, which is a rewriting of the Seventh Crusade, the narrator observes:

'Adnān looked everywhere, searching for any kind of leadership that was steering the crowds that poured down from the remotest parts of Egypt, [...] but found nothing other than the endless human waves, with no crowned king or a scepter-bearer. 'Adnān cried: this is the leadership I choose to fight with; these simple commoners are the leaders and the

155 Id., Riḥlatī, p. 33.

156 'Ali Frayğ, "Interview," Mağallat al- Šihāb, 5/1 (1971); reprinted in al-Kīlānī, Riḥlatī, p. 228.

157 Id., al-Nidä’, p. 166. 
soldiers; their rough and bony hands are the makers of glory and glorious history. ${ }^{158}$

\section{Female "Intrusion"}

The portrayal of woman is another dilemma that will always confront the Islamic storyteller: ${ }^{159}$ questions relating to the praxis of the female's presence, the space she occupies, and the type and size of roles assigned to her; how, or even whether, female characters should participate in and influence action. Some critics pronounce their objection to the persistent presence of female characters in al-Kïlānì's novels, often with the same weight as their male counterparts. ${ }^{160}$ It is true that female representation is a foundational phenomenon in al-Kìlānī's œeuvre. All his novels without exception include important female characters; a matter, he opines, that is imperative in any Islamic fiction, following the example of the Koran, where women, all kinds of them, are present and quite active. ${ }^{161}$ Intriguingly, the main character in his novel on the ordeals of the Brotherhood is a young female history teacher; which serves many purposes, not least among them innovation and drawing on the reader's sympathy.

Yet, at the same time, al-Kīlānī seems to have his own restrictions on the subject; criticizing Egyptian media for the type of niche they preserve for woman, - the helpless, the victimized, the promiscuous rebel, or the trivialized mind. ${ }^{162}$ Alternatively, whether good or villainous, most of the female creations of his imagination are active, intelligent, with plenty of will power and self-determination. Even the illiterate Bedouin girl from a Gulf country, the heroine of his Amirat al-ğabal (The Mountain Princess), contrives to escape the oppressive tribal traditions; her path goes parallel to that of the Iraqi doctor she falls in love with, who is forced into diaspora to escape political tyranny and persecution. It may be one of al-Kilānīs major achievements that he has taken great pains to vividly portray female characters, to patiently scrutinize their inner world, and fairly individuate each and every one of them, from the simplest villager in $F \grave{l} l$-zala $m$ to the most sophisticated, liberated, secularized

\footnotetext{
$15^{8}$ Id., al-Yawm al-maw'ūd, Beirut, Mu’assasat al-risāla, 1981, p. 67.

159 For a full discussion of this topic in the context of al-Kïlāni’s work, see Khawaldeh, "al-Mar’a."

16o Brīğš, Dirāsāt, p. 51 .

161 Al-Kỉlānī, Hawl al-qișșa l-islāmiyya, p. 41.

162 Id., al-Islām wa-harakat al-hayā, Beirut, Mu’assasat al-risāla, 1992, vol. 2, p. 10.
} 
professional in Riğăl wa-diāb (Men and Wolves). Even the stereotypical figure of prostitute is humanized, as in Qâtil Hamza (Hamza's Killer), where she is given a chance of ennoblement.

Two of his heroines merit a closer investigation: Wahïba in Layl al-hațāya (The Night of Sins, 1960) and Barāim in Malikat al-inab (Queen of the Grapes, 1991), each representing one of two distinct phases in his fiction writing career: the early mainstream and the later explicitly Islamic, a distinction drawn by al-Kīlānì himself in Rihlatī. Wahība dominates the whole novel with her overwhelming physical desire for her youthful brother in law,- - an obsession that almost destroys her little world and its simple inhabitants; yet the end is not apocalyptic; the author leaves room for repentance and the promise of forgiveness. It may well exemplify "optimism," designated as a characteristic of Islamic fiction.

The novel takes up a psychoanalytical track to convincingly effect the perfect wife's transmutation into a malicious schemer as a result of traumatic childhood with a cruel father. Nevertheless, the plot is arrayed in a credibly realistic configuration, divulging the macrocosmic misery of the Cairene poor. Naturally, such anatomy of the development of the adulterous affair and the psychology of the sinning mind, has affronted al-Kilānī's critics, ${ }^{163}$ but his rationale, as he rejoins, is that although the principle of "pure ends require pure means" is true, in fiction writing this takes a rather complex route, for we should not lie about our sick reality nor falsify history. ${ }^{164}$ Apparently, he is thinking that the novel conveys a process of becoming, of "purifying," emerging out of the obnoxiousness of the moment. "Only by portraying the madness of sexual desire," chastity's goodness and beauty are illuminated. 165

None of those critics alludes to or indicates awareness of the thematic structure of the plot obviously designed to parallel the archetypal story of Prophet Joseph in the Koran, a key influence on al-Killann's fiction. Fascinated with the story, presented in the Koran in an exceptionally complete episodic narrative, he cites it more than once. ${ }^{166}$ It seems to inspire him with the idea that there

\footnotetext{
163 A researcher mentions that al-Kīlānī firmly refused the reprinting of his novel Layl alhațāya for its un-Islamic content ('Arrīnī, Al-Ittiǧāh, p. 18). However, its title reappears in the index of "By the same author" at the end of the 1994 editions of several of his novels just before his death. Also in his Rihlatī (1985), p. 53, al-Kīlānī confirms that he has decided to keep all his early fiction exactly as it has been first published, declining a publisher's suggestion to make some revisions, and opting to leave it for the literary historian to trace the evolution of his career.

164 al-Kìlānī, Rị̣latī, p. $5^{2}$.

165 Ibid., p. 54.

166 Id., Madhal ilà l-adab al-islāmì, p. 114; id., al-Islāmiyya, p. 56 ff.
} 
is plenty of room in Islamic literature for the rendering of evil and sexuality, and to provide him with directives on the appropriate representations of both. "The model introduced in the sura of Joseph may demarcate the boundaries we must not break;" 167 boundaries further elucidated in an earlier statement: "Sex," he writes, "a fact of life and an important subject even in the Koran, has to be depicted subtly, cautiously and decently."168 He also writes,

Our conception of sex must be clear, with no complexities; for [...] the Koran renders it in a long story, where an audacious woman, physically obsessed by lust for Joseph, a Prophet of God, defies social values and traditions [...], and boasts in front of the women of the city about her determination to satiate that sinful [desire]. ${ }^{169}$

As an artist, he argues against his critics' "thou-shalt-not" rule when it comes to

representations of woman and her feelings, sexual relationships, and similar, possibly embarrassing topics; or obscene words not condoned by religion and refinement. The taboo circle drawn by some 'ulam $\bar{a}^{\prime}$ is so widened as to hinder the important literary imperative of drawing identifiable characters by putting credible language in their mouths. ${ }^{170}$

The centrality of the debate starts with the inception of the very idea of Islamic literature. In his 1952 article, Sayyid Quṭ defines what he sees as the right approach to the portrayal of "human weakness," i.e. sin and evildoing, writing,

Literature or art generated from an Islamic conception of life may sometimes cover moments of human weakness, but it dwells on them only to attempt to raise humanity from the pits of such moments, and to free it from the fetters of necessity and its exigencies. ${ }^{171}$

To go back to Barāim in Malikat al-inab, written thirty years later, where we are introduced to one of the rare role models offered by al-Kìlānī, and perhaps a case of writing back, considering the time of its genesis; i.e. the aggressive interrogations and doubts concerning women's rights and roles in Islam, as well

167 Frayğ, "Interview," p. 229.

168 Al-Kīlānī, al-Islāmiyya, p. 56.

169 Id., Madhal ilā l-adab al-islāmī, p. 114.

170 Ibid., p. 100.

171 Sayyid Quțb, Fì l-tārīh, p. 6. 
as the injustices suffered by women in the status quo. With little education and a dependent all-female household to provide for: a sickly mother and two younger sisters, Barā'im expands her farming business with a shrewd sense of entrepreneurship and outstanding stamina, earning her position as leader of the grape business owners, as well as of her rural community. A bystander, a prominent man in the village, praises her achievement and charitable work, tagging what may be the underlying message, "this is true Islam. If we want Islam in our society, we must begin with ourselves, our families, and then our little villages."172

The abstraction in these words is quite normal in Egyptian, even Arabic daily discourse: to compare the real with the ideal in the context of Islam, most evidently in the political motto "Islam is the solution." But, is al-Kîlānī deviating from his no-Islamic-jargon rule? Or is he, in the name of realism, honestly recording visible changes in the Egyptian political and ideological scene? What is certain is his opinion published in 1985 about the normalcy of the apparently incongruous phenomenon of the writer adopting various traditions from different literary schools. ${ }^{173}$ Yet, further analysis shows that it is not a matter of metamorphosis of the author; rather, it is the destiny of the realistic novel to be tightly bound to social and spatial changes. Thus, the degree of Islamicity in al-Kïlān's work grows higher as the Islamic movement attains more visibility after the end of Nasser's regime in 1970. Another point to consider here is that the bystander's voicing of such generalizations has already been extant in alKìlān's known world from the beginning, but its registering in literature has become more possible in the slow regaining of more breathing space by the movement.

\section{Conclusion}

Unlike his critics, al-Kỉlānì is basically a creative writer whose greatest worry is not to draw perimeters and distinguishing features in the abstract, though he has done that, but to produce a literary corpus worthy of his own as well as of many others' description of Islamic literature. Compared to contemporary Arabic fiction, his work partially fulfills the promises Clifford Edmund Bosworth discerns in other mainstream novels:

172 Al-Kīlānī, Malikat al-'inab, Beirut, Mu'assasat al-risāla, 1992, p. 138.

173 Id., Rihlatīi, p. 6 o. 
[They] show many penetrating insights into aspects of contemporary Arab society: in the macrocosm, the splendors and miseries of its adjustment to the larger world, and the counter-movement of its rejection and withdrawal from it. ${ }^{174}$

Yet, al-Kìlānì's protagonist is mainly one of the markers that separate his novel form mainstream fiction because he/she is rarely the outsider, that "archetypical figure of recent Western literature" Bosworth finds in contemporary Arabic literature, ${ }^{175}$ for al-Kīlānī is as anti-modernist as Lukács; more of an artist with a mission, trying rather to follow the footsteps of Iqbal and Gorki. Al-Kìlānìs way of framing art is to assign supremacy to the ideal, albeit sometimes shadowy, over the real, and to turn those rather hopeless utopian notions into images of possibility; a venture new and still in the stage of familiarization in the contemporary Islamic context. "My quest," he declares, "has always been to find the virtuous city, the Islamic Utopia." ${ }^{176} \mathrm{He}$ seems to have thought of his art as a pioneering project to be scrutinised and negotiated, and not the gesture of a partisan tied to the rules and principles of an ideological body.

Muștafā Maḥmūd (1921-2009), an ex-Marxist and a fellow Islamic author, may well be quoted, in conclusion, to best speak for a class of writers that may well include al-Kīlānī:

I have never been a religious scholar; I entered the realm of religion by divine grace, by love and faith, not through the gates of al-Azhar. I am like the poet who loved God and so wrote Him a poem and built Him a house, but always as the artist by nature. [...] Art has always been my vulnerability and powerfulness. ${ }^{177}$

The class can boast of members such as Ṭāhā Ḥusayn, al-Ḥakīm and other "artists" who step into the field of religion, not with the authority of a Šāfici or an Ibn Hanbal, rather as those lovers who talk to us about God in a new language. ${ }^{178}$ It is this subtle, suggestive, less assertive approach to knowledge, the religious in particular, that accounts for the literariness and artfulness of the endeavor.

174 Clifford Edmund Bosworth, "Preface" in Roger Allen, The Arabic Novel: An Historical and Critical Introduction, Syracuse, Syracuse University Press ("Journal of Semitic Studies Monograph", 4), 1982, p. 7 .

175 Ibid., p. 7 .

176 Al-Kīlānī, Riḥlatī, p. 96.

177 Mușțafā Maḥmūd, al-Masĭh al-dağğāl, Cairo, Dār al-macārif, n.d., p. 4.

178 Ibid., p. 5 . 